
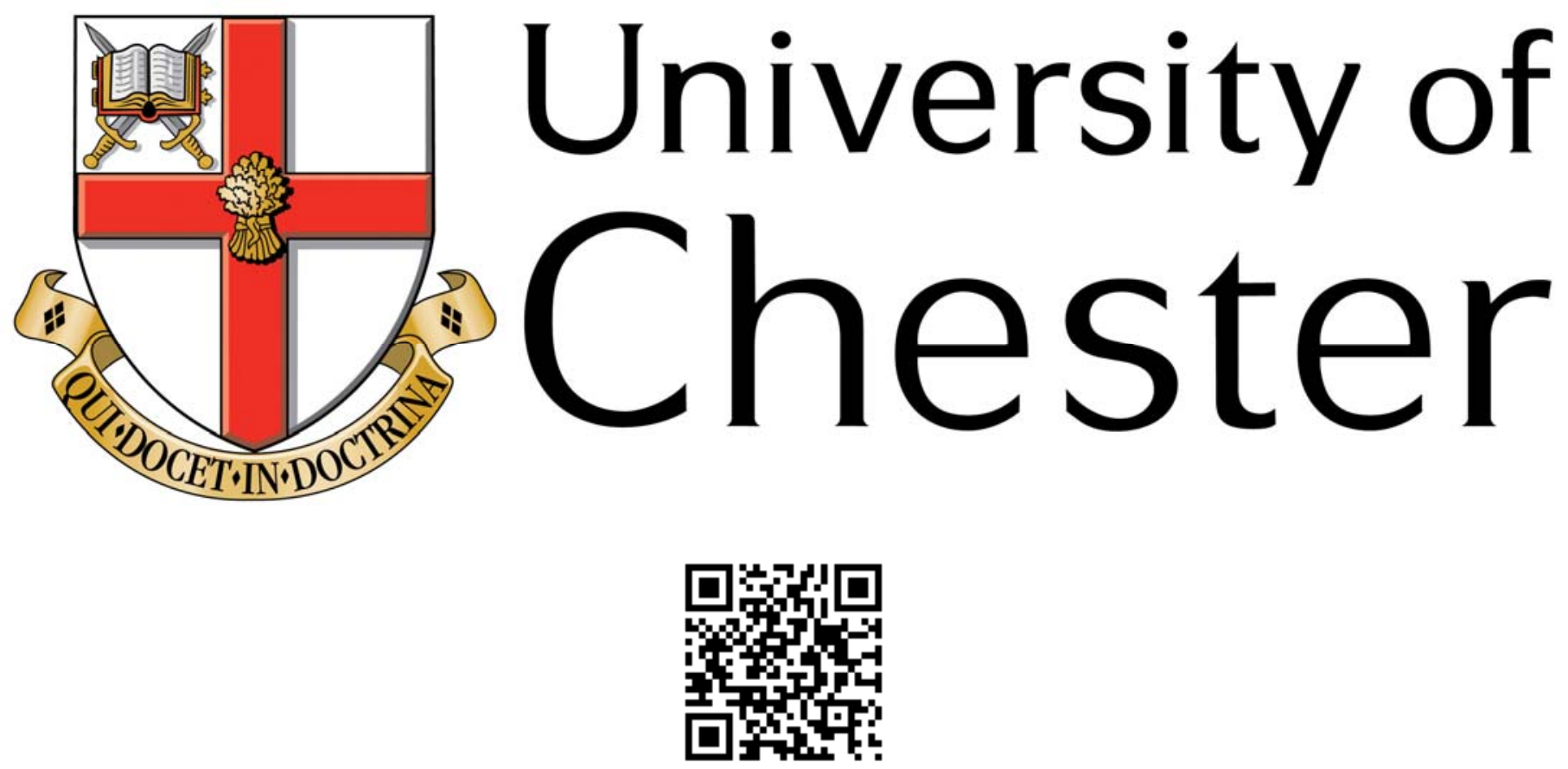

This work has been submitted to ChesterRep - the University of Chester's online research repository

\title{
http://chesterrep.openrepository.com
}

Author(s): Tom Greggs

Title: Exclusivist or universalist? Origen the 'wise steward of the word' (CommRom. V.1.7) and the issue of genre

Date: 2007

Originally published in: International Journal of Systematic Theology

Example citation: Greggs, T. (2007). Exclusivist or universalist? Origen the 'wise steward of the word' (CommRom. V.1.7) and the issue of genre. International Journal of Systematic Theology, 9(3), 315-327

Version of item: Author's post-print

Available at: http://hdl.handle.net/10034/88395 


\title{
Exclusivist or Universalist? Origen the 'Wise Steward of the Word' \\ (CommRom. V.1.7) and the Issue of Genre
}

\section{TOM GREGGS}

Jesus College, Cambridge

\begin{abstract}
This article explores the issue of Origen's universalism. It identifies the two seemingly self-contradictory strands in the Origen corpus which have led to dual pictures of Origen as either an arch-universalist or an exclusivist. To make sense of this, the hermeneutical key of CommRom. V.1.7 (in which Origen states Paul covers over his universalism to be a 'wise steward of the word') is applied to Origen's own texts. Identifying the different genres in Origen's works, it is clear that different stances on universalism are taken dependent upon the genre of his work. The question is posed as to whether such a move in theology is justifiable and biblical.
\end{abstract}

In the early church, the two principal ways of Christianity dealing with the salvation of the non-Christian were in terms of the exclusivist rejection of the possibility of salvation for those outside the Christian church, ${ }^{1}$ or else by the quieter strand of the tradition which extended the hope of salvation to all humanity, grounding this in a universalist approach to soteriology. ${ }^{2}$ In Origen, rather confusingly, one sees both approaches to the issue of ultimate salvation. Despite the traditional picture of Origen as the arch-universalist, promising salvation even for the devil (according to

\footnotetext{
${ }^{1}$ As seen, for example, in the likes of Irenaeus, who anticipated the unjust to be doomed to eternal separation from God (Ad. Haer. V).

${ }^{2}$ For a brief history of these two strands of thought in the patristic era, see Morwenna Ludlow, Universal Salvation: Eschatology in the Thought of Gregory of Nyssa and Karl Rahner (Oxford: Oxford University Press, 2000), pp. 30-44.
} 
certain readings of De Princ. I.5.2), ${ }^{3}$ revisionist historians of early dogma have increasingly presented a picture of a more moderate and orthodox Origen whose

theology offers a salvation limited only to the church, and even then only to the best of its members. The presentations of the likes of Fredrick W. Norris seem to leave one wondering why the charge of universalism was ever brought against Origen. ${ }^{4}$ One must certainly agree with de Lubac that the fifth ecumenical council condemned Origenism rather than Origen. ${ }^{5}$ Yet when so sympathetic a commentator as Daniélou identifies Origen's use of apokatastasis as a defective element of his theology built upon Platonic philosophy rather than Christian tradition, ${ }^{6}$ it seems one should not simply be suspicious of Origen's enemies on the matter of universalism given that even his friends identify it there critically.

\footnotetext{
${ }^{3}$ Modern systematic theologians have tended to take this view of Origen, using 'Origenism' almost as a synonym for unquestioned universalism without an appreciation of more careful studies of the Alexandrian. One can see an example of this even in Barth, who considered that Origen offered salvation even to the devil by reason of a general apokatastasis. See Karl Barth, Church Dogmatics III/3 (Edinburgh: T. \& T. Clark, 1960), p. 300. Hunsinger similarly presents Origen as an unquestioned universalist, comparing him to Bishop Robinson. See George Hunsinger, Disruptive Grace: Studies in the Theology of Karl Barth (Grand Rapids: Eerdmans, 2000), pp. 234-9. Nor is this view only limited to Barthian readings of the history of dogma. Tillich also accepted the church's traditional teaching on Origen, claiming the expectation of apokatastasis as Origen presented it 'seemed to remove the seriousness implied in such absolute threats and hopes as "being lost" or "being saved" '. See Paul Tillich, Systematic Theology Vol. III (Welwyn: Nisbet, 1964), p. 434.

${ }^{4}$ Modern systematic theologians have tended to take this view of Origen, using 'Origenism' almost as a synonym for unquestioned universalism without an appreciation of more careful studies of the Alexandrian. One can see an example of this even in Barth, who considered that Origen offered salvation even to the devil by reason of a general apokatastasis. See Karl Barth, Church Dogmatics III/3 (Edinburgh: T. \& T. Clark, 1960), p. 300. Hunsinger similarly presents Origen as an unquestioned universalist, comparing him to Bishop Robinson. See George Hunsinger, Disruptive Grace: Studies in the Theology of Karl Barth (Grand Rapids: Eerdmans, 2000), pp. 234-9. Nor is this view only limited to Barthian readings of the history of dogma. Tillich also accepted the church's traditional teaching on Origen, claiming the expectation of apokatastasis as Origen presented it 'seemed to remove the seriousness implied in such absolute threats and hopes as "being lost" or "being saved" '. See Paul Tillich, Systematic Theology Vol. III (Welwyn: Nisbet, 1964), p. 434. See Fredrick W. Norris, 'Universal Salvation in Origen and Maximus', in Nigel M. de S. Cameron, ed., Universalism and the Doctrine of Hell. Papers Presented at the Fourth Edinburgh Conference on Christian Dogmatics 1991 (Carlisle: Paternoster, 1992), pp. 35-72, esp. pp. 35-58.

${ }^{5}$ Henri de Lubac, Histoire et Esprit: l'intelligence de l'Écriture d'après Origène (Paris: AubierMontaigne, 1950), pp. 13-91.

${ }^{6}$ Jean Daniélou, Origen (London: Sheed \& Ward, 1955), pp. 288f. Crouzel similarly sees pre-existent souls as having their origin in Platonism. See Henri Crouzel, Origen (Edinburgh: T. \& T. Clark, 1989), p. 207. For a response to this view of Origen's relationship to Platonism, see Mark J. Edwards, Origen against Plato (Aldershot: Ashgate, 2002).
} 
How, then, is one to respond to this dual picture of Origen? Most certainly the divergent views arise from two strands of Origen's theology both present within the existing corpus. This article will identify those two strands of teaching on how to relate to salvation to those outside of the faith of the church, and consider whether the mutually exclusive presentations of Origen described result from mutually exclusive positions within his own theology. It will advocate that this is not the case, but rather arises from a distinction in the genres of Origen's works. This move will be justified through examination of the texts and the hermeneutical key of CommRom. V.1.7 in which Origen states that St Paul is covering over his universalism in order to be a 'wise steward of the word'. It will be advocated that Origen, too, follows the path he believes St Paul does, and - in order to be a 'wise steward of the word' himself approaches the issue of universalism differently dependent on the different genres of his works.

\section{The two strands of Origen's thought on universalism}

In an age in which there was no regula fidei on eschatology, Origen's at times denial and at times championing of the cause of universalism cannot be attributed to any reticence on his part to depart from the church's teaching, nor indeed to disguise his thoughts from church authorities. In many ways, his own universalism builds upon the work of Clement of Alexandria. ${ }^{7}$ Furthermore, the issue of translation cannot be brought to bear on the matter: the more universalist passages (as will be seen) are scattered throughout both the Greek and the Latin. If Rufinus' desire was to guard his master from the condemnation of later orthodoxy by limiting salvation only to those inside the church, he did not do so by removing every vestige of the doctrine of

\footnotetext{
${ }^{7}$ See Ludlow, Universal Salvation, pp. 31ff.
} 
apokatastasis. ${ }^{8}$ In Origen, there are clearly two strains of thought on universal salvation, and these must be examined albeit briefly.

The strain of thought traditionally attributed to Origen comes from a discussion which follows the reading of his works primarily through De Princ. This is Origen's only directly systematic work. In it is contained his most (in)famous belief in apokatastasis, or the universal restoration of all things. Given Origen's discussion of pre-existent souls which have cooled from the divine fire (hence the word $\psi u x \grave{\eta}$ comes from $\psi \mu \tilde{x} \varepsilon \sigma \theta \alpha$ ) (De Princ. II.8.3), the important element of apokatastasis for Origen is 'restoration'. He writes:

$\therefore$ when the Son is said to be subjected to the Father the perfect restoration of the entire creation is announced, so when his enemies are said to be subjected to the Son of God we are to understand this to involve the salvation of those subjected and the restoration of those that have been lost. (De Princ. (II.5.7) $)^{9}$

Thus, eschatology is seen as the 'perfect restoration of the entire creation' (perfecta universae creaturae restitutio) which includes the 'restoration of the lost' (reparatio perditorum). Both restitutio and reparatio have the sense of returning to something that was before. Given that souls have cooled from the divine fire, this presumably means a restoration to a life that was in communion with God - restoration to a full participation in God that the soul once enjoyed. ${ }^{10}$ This is to be the time when God will

\footnotetext{
${ }^{8}$ Indeed, Crouzel and Simonetti suggest that Rufinus was an accurate translator. See Henri Crouzel and Manlio Simonetti, eds., Traité des principles I-V, Sources chrétiennes [SC] 252, 253, 268, 269 (Paris: Les Éditions du Cerf, 1978-84), esp. SC 252, pp. 23-46. On Rufinus as a translator, see also, for example, Ronald E. Heine, trans. and ed., Origen Homilies on Genesis and Exodus, The Fathers of the Church (A New Translation), vol. 71 (Washington, DC: The Catholic University of America Press, 1982), pp. 30-39; Annie Jaubert, Origène: Homélies sur Josue, SC 71 (Paris: Les Éditions du Cerf, 1960), esp. pp. 68-70.

${ }^{9}$ Quotations from De Princ. are taken from George W. Butterworth, Origen On First Principles: Being Koetschau's Text of the De Principiis into English, Together with an Introduction and Notes (Gloucester, MA: Peter Smith, 1973). Latin and Greek texts are taken from Crouzel and Simonetti, Traité des principles $I-V$.

${ }^{10}$ We see this theme of restoration similarly presented in CommJoh. In this, he writes: 'I think its stopping point and goal is in the so-called restoration because no one is left as an enemy then, if
} 
be 'all in all' (1 Cor. 15:28): 'that when "God shall be all in all," they also, since they are a part of all, may have God even in themselves, as he is in all things' (De Princ. I.7.5). This refers to all things at the end of creation: nothing seems to be left out since God is 'all in alr. What takes place in this is salvation in which the soul is saved by becoming (in a slightly different way) a second time what it was before (De Princ. (1.8.3). ${ }^{11}$

This means, therefore, that punishment in Origen's theology is not absolute ( $D e$ Princ. II.10.7). Its purpose is instead to reform the soul in order that it can be restored to what it previously was (De Princ. 1.6.3). Although Origen does discuss those 'separated from every gleam of reason and intelligence' who will be clothed in darkness and live as if in a prison (De Princ. II.10.8), there is little sense of a permanent hell in Origen's thought. ${ }^{12}$ Origen's sense of the graciousness of God always allows for a further opportunity of salvation for all people in future aeons. Thus, he writes in another theological treatise:

And in those ages to come God will show the riches 'of His grace in kindness,' since the worst sinner, who has blasphemed the Holy Spirit and been ruled by sin from beginning to end in the whole of this present age, will afterwards in

indeed the statement is true, "For he must reign until he has put all his enemies under his feet. But the last enemy to be destroyed is death" ' (CommJoh. 1.91). Here Origen describes the end as $\pi \eta^{\prime}$

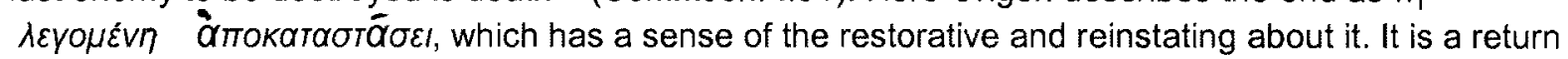
to how things originally were. For Origen, this seems to be a universal reinstatement, since there remains 'no enemy' against whom to fight. Quotations from CommJoh. are taken from Ronald $E$. Heine, Origen Commentary on the Gospel According to John. The Fathers of the Church (A New Translation), vols. 80 and 89 (Washington, DC: The Catholic University of America Press, 1989, 1993). Greek quotations are taken from Cécile Blanc, Origène. Commentaire sur saint Jean, SC 120 , 157, 222, 290, 385 (Paris: Éditions du Cerf, 1966-92).

${ }^{11}$ Yet this is not in the Stoic sense of cyclic and endless determinism, but one in which there is progress and growth in the process. Origen believes cyclical views of eternity would mean that there was doubt as to the efficacy of Christ's death and resurrection (based on 1 Cor 15:28). Therefore, the end is not exactly as the beginning (De Princ. III.6.3). The idea that Origen subscribed to successive cycles of fall and redemption is rightly rejected by Brian $E$. Daley, The Hope of the Early Church: $A$ Handbook of Patristic Eschatology (Cambridge: Cambridge University Press, 1991), p. 58; Crouzel, Origen, pp. 157, 205; and Ludlow, Universal Salvation, p. 36.

${ }^{12}$ See, for example, Mark J. Edwards, 'Origen's Two Resurrections', Journal of Theological Studies 46 (1995), pp. 502-18, esp. pp. 510-13. Cf. Henri Crouzel, 'Hadès et la Géhenna selon Origène', Gregorianum 49 (1978), pp. 291-331. 
the age to come be brought into order, I know not how. (On Prayer XXVII.15) $)^{13}$

Even those seemingly beyond any salvation in the present age will receive grace in the future. The will of God must be done for the unjust as for the just, and for the incontinent as for the continent (On Prayer XXVI.6). This is because the end is always like the beginning for Origen (De Princ. I.6.2). Thus, no created thing escapes restoration to its beginning with the Logos.

As well as the overt universalism discussed, there are many other passages which point in a universalist direction. Origen is emphatic in his insistence that Jesus came for the benefit of the whole human race. Christ is called 'saviour of all men' (CCel. IV.4) ${ }^{14}$ who takes away the sin 'not of a few, but of the whole world' (CommJoh. VI.284). To name but a few further examples, universalism can be seen in the following: CommMt. X.2 points to sins rather than people being subject to judgement; CommRom. V.2.2 sees Christ's saving work as greater than the transgression of Adam; and CommRom. V.2.8 sees Christ leading more back to life than Adam led to death. Universalism is also hinted at in HomLev. VII.2.9ff. through the image from Ezekiel of the dry bones, and HomLk. f.214 which sees Christ as the Saviour even of people in hell.

However, this seems to be an area of Origen's thought where he is not as clear as one might hope, and is being justifiably - given the nature of the subject speculative. If one reads the issue primarily though Origen's biblical works, there is a far greater sense of exclusivism. There are several instances in which salvation seems to be limited in Origen's theology. He writes, for example,

\footnotetext{
${ }^{13}$ Translation from Rowan A. Greer, 'On Prayer', in Origen (New York: Paulist Press, 1979).

${ }^{14}$ Translations for $\mathrm{CCel}$. are taken from Henry Chadwick, Contra Celsum (Cambridge: Cambridge University Press, 1965).
} 
Outside this house, that is, outside the Church, no one is saved [extra ecclesiam, nemo salvatur]. If anyone goes outside, he is responsible for his own death. (HomJosh. III.5) ${ }^{15}$

Nor is this exclusivism limited to the passages in Latin: the Greek HomJer. speaks of an eternal fire from the devil for the evil, without the possibility of being remade in some future age (HomJer. XVIII.1); CommJoh. limits rationality and life (which is participation in the Logos by which salvation will come) only to those inside faith in Christ, thus suggesting only the saint is restored and truly 'is' (CommJoh. II.114f.). Many other such indicators of a limited salvation also exist. One sees this, for example, in the likes of CCel. IV.4 (in which universalism seems simply to mean people from all nations compared to what Origen sees as geographical exclusivism), III.81, IV.10; and exclusivist passages can be noted at HomGen. 2.3; HomLev. V.7.2, VII.6.4; and throughout CommRom. ${ }^{16}$ In HomEx., HomLev. and HomJer., as well as CommMt., there is a clear indication of punishment for all sinners. Even De Princ. devotes a whole chapter to 'The Resurrection and Punishment' (De Princ. II.10), and has the suggestion there is hell for those beyond understanding (De Princ. II.10.8). Furthermore, despite later charges, the devil is destined to hell with the demons according to HomJosh. XIV.2 and Origen's letters to Alexandrian friends. ${ }^{17}$

Brief as this description has been, it does highlight two modes of thinking in Origen's inner logics - the one which is optimistic for all creation, the other which recognizes

\footnotetext{
${ }^{15}$ Translations for HomJosh. are taken from Barbara J. Bruce, Origen's Homilies on Joshua, The Fathers of the Church (A New Translation), vol. 105 (Washington, DC: The Catholic University of America Press, 2002). According to von Harnack, this passage indicates Rufinus' echoing Cyprian's 'Salus extra ecclesiam non est' (Ep. 73.21, CSEL 3.2, p. 795). Adolf von Harnack, Der kirchengeschichtliche Ertrag der exegetischen Arbeiten des Origenes (Leipzig: Hinrichs, 1918), p. 83 n. 2.

${ }^{16}$ See, for example, III.1.3, V.1.29, V.1.37, VIII.7.2.

${ }^{17}$ Albeit these are only in Latin and may indicate a desire on Rufinus' part to make Origen more palatable to the orthodoxy of later generations through his own translation, using Origen's own letters to defend him.
} 
the seriousness of hell and judgement. How are these two strands of thought to be united? It is to this which it is necessary now to turn.

\section{Uniting the mutually exclusive}

Opposing as these modes of thinking may at first seem, they are not necessarily mutually exclusive. The remedial, pedagogical and purgatorial nature of punishment indicate that in Origen hell is not eternal. Certainly, this is how to understand the ideas of judgement, hell and punishment in De Princ. The fire is something one kindles against oneself in recognition of one's own sin (De Princ. II.10.4). The punishment that ensues is a punishment for restoration, in which God acts as a physician (De Princ. II.10.5f.). Punishment is not, therefore, absolute (De Princ. II.10.7). Perhaps it is, as traditional interpreters have suggested, through this early work of Origen's that all his other works are to be understood? ${ }^{18}$ After all, one sees similar logic used in HomEz. and HomJer.: punishment is used to chastise but not eternally and not to destroy; the fire of hell is to be a deterrent to shape the moral lives of Christians. ${ }^{19}$ Furthermore, in CommMt. and elsewhere, the two resurrections seem to imply that saints have already been purged and are resurrected while sinners still require purging. ${ }^{20}$

This may be so, but it does not explain the different tone of the more optimistic aspects of theology to the more judgemental and forewarning messages of Origen. Some commentators have rightly pointed to the dangerous anachronism of making

\footnotetext{
${ }^{18}$ That said, the dating of De Princ. is a controversial matter. See Butterworth, On First Principles, pp. xxviii-xxx.

${ }^{19}$ HomJer. XIX.15, XX.4; HomEz. I.13.

${ }^{20}$ See CommMt. X.3; for comments on these two resurrections and further textual analysis, see Edwards, 'Origen's Two Resurrections'.
} 
Origen overly systematic, conforming him to the views held by theologians of the present generation. ${ }^{21}$ There is much to be said for this, but the theologian cannot simply stop there. The question arises, given that Origen does have these two strands of thought: why does he have them? Pointing, as Norris does, to the fact that he is a biblical theologian who does not find a single voice in scripture is valid and fair. However, this does not account for why he allows one voice to speak more loudly at certain times and another at others.

It is here where the hermeneutical key of CommRom. V.1.7 must be employed. Origen comments on 1 Cor. 15:33f.:22

Paul is thus acting as a wise steward of the word. And when he comes to the passages in which he has to speak about God's goodness, he expresses these things in a somewhat concealed and obscure way for the sake of certain lazy people lest, perchance, as we have said, 'they despise the riches of his goodness and patience and forbearance and store up for themselves wrath on the day of wrath' ... (CommRom. V.1.7) ${ }^{23}$

Origen suggests here that St Paul is acting as a 'wise steward of the word' to conceal and obscure the goodness of God in the universalist passages which have preceded 1 Cor. $15: 33^{24}$ in order that the weaker are not tempted to fall back into sin. This is a much commented on element of Origen's exegesis - the deliberate

\footnotetext{
${ }^{21}$ Norris, 'Universal Salvation in Origen and Maximus', p. 58.

22 'Do not be deceived: "Bad company ruins good morals." Come to a sober and right mind, and sin no more; for some people have no knowledge of God. I say this to your shame.' All biblical quotations are taken from the New Revised Standard Version.

${ }^{23}$ Translations of CommRom. are taken from Thomas P. Scheck, Origen Commentary on the Epistle to the Romans, The Fathers of the Church (A New Translation), vol. 103 (Washington, DC: The Catholic University of America Press, 2001).

${ }^{24}$ 'Then comes the end, when he hands over the kingdom to God the Father, after he has destroyed every ruler and every authority and power. For he must reign until he has put all his enemies under his feet. The last enemy to be destroyed is death. For "God has put all things in subjection under his feet." But when it says, "All things are put in subjection," it is plain that this does not include the one who put all things in subjection under him. When all things are subjected to him, then the Son himself will also be subjected to the one who put all things in subjection under him, so that God may be all in all' (1 Cor. 15:24-28).
} 
deception of scripture for the sake of salvation. ${ }^{25} \mathrm{~A}$ similar position is held in CommRom. V.2.6 where Origen suggests Paul designates 'all men' as 'many' in order to point to sin and death, and to stop people from becoming lazy in their obedience. While this point is well observed in scholarship, what is less well observed is that it may well equally be applied in the same way to Origen's own teaching and theology as he applied it to St Paul.

Indicative of Origen's reading of St Paul, it may well be that the dual strands of thinking in his own work are the result of a desire also to be 'a wise steward of the word' himself. When one looks carefully at the differing positions (or at least tones) on universalism of the different genres of Origen's writing, it seems this is certainly his concern. ${ }^{26}$ Moreover, one should not underestimate the importance of pastoral concern for the new converts and catechumens for Origen the didaskalos and later priest and preacher.

In considering the nature of Origen's eschatology in his different works of theology, an interesting pattern emerges. De Princ., his most 'systematic' work, is also his most clearly universalist in direction. While there are passages which indicate the existence of hell and punishment, it is clear that these are not permanent, but rather remedial. ${ }^{27}$ The soul is, therefore, subjected to torture for purification rather than

\footnotetext{
${ }^{25}$ See Joseph W. Trigg, 'Divine Deception and the Truthfulness of Scripture', in Charles Kannengiesser and William L. Petersen, eds., Origen of Alexandria: His World and His Legacy (Notre Dame, IN: University of Notre Dame Press, 1988), pp. 147-64; and Richard P.C. Hanson, Allegory and Event: A Study of the Sources and Significance of Origen's Interpretation of Scripture (London: SCM Press, 1959), pp. 228ff.

${ }^{26}$ In the fourth century, with the increased need for clear propositional answers, Origen was seen as a two-faced monster - covering over his heterodoxy with elements of orthodoxy, which led to the criticism of inconsistency. See Rufinus's Epilogue to Pamphilus the Martyr's Apology for Origen (Nicene and Post Nicene Fathers, Vol. III). Clearly, albeit in a slightly different way, Origen's early attackers and apologists recognized the variety in his theological positions.

${ }^{27}$ For example, 'when the soul, thus torn and rent asunder, has been tried by the application of fire, it is undoubtedly wrought into a condition of stronger inward connexion and renewal' (De Princ. II.10.5). Cf. De Princ. II.5.3, II.10.6.
} 
destruction. The individual continues to be purged from their sin in a punishment which does not appease the wrath of God, but helps to restore the human being to the perfect creation made by God. It is difficult to doubt that the ultimate position of De Princ. is universalist. Problematic as it may be to construct such a group, if one were to consider an audience for this work, it may well seem that Origen did not need to be so guarded as he is elsewhere on the issue. This is not the place for a detailed discussion of a prospective audience. ${ }^{28}$ However, a work which combines both philosophy and biblical studies might be considered for the more 'advanced' in faith and understanding, or simply those who also wrestled with scripture and philosophy. ${ }^{29}$ But perhaps that is to ask the wrong question. ${ }^{30} \mathrm{~A}$ work which is in many ways the precursor of later systematic theology is able to place the doctrine of apokatastasis within the broader context of Christian theology, protecting its readers from divorcing this teaching from the doctrine of sanctification and the need for spiritual progression. This more systematic presentation of universalism Origen gives

\footnotetext{
${ }^{28}$ Descriptions of the audience for De Princ. are many and varied. However, it seems difficult to agree with Butterworth, following de Faye, that the work was designed simply to take the place of the didaskalos (Butterworth, On First Principles, pp. xxx-xxxi). Even if the book deals with questions raised in the school, it is hard to imagine the responses as being entirely appropriate for the average catechumen. Far better is to see the work along with Trigg as one comprised of 'doctrines which the biblical authors, enlightened by the Logos, placed in Scripture so that those who devote themselves to the deep things of God (see I Cor. 2.10) might seek them out and which the Spirit of God deliberately concealed from those unable to bear the toil of such investigation'. J.W. Trigg, Origen (London: Routledge, 1998), p. 22.

${ }^{29}$ It is difficult to imagine any person ignorant of the subtleties of philosophy reading such a piece, or at least any ancient who did not see the effect of philosophy on one's life. See Pierre Hadot, What is Ancient Philosophy?, trans. Michael Chase (Cambridge, MA: Belknap Press of Harvard University Press, 2002). Hadot writes: 'As ancient philosophical discourse was for the philosophical way of life, so Christian philosophical discourse was a means of realizing the Christian way of life' (p. 240). Those schooled in philosophy would have recognized that the implication of Origen's 'system' was a Christian way of life, not the non-necessity of faith.

${ }^{30}$ It may well be best not to worry too greatly about the nature of the audience, and instead to look at the nature of the book on this point. Here, McGuckin seems most accurate in seeing the work as in some way the first ever 'theology handbook'. See John A. McGuckin, ed., The Westminster Handbook to Origen (Louisville, KY: Wesminster John Knox Press, 2004), p. 36. Certainly, in Origen's own words, he addresses '[e]veryone ... who is desirous of constructing out of the foregoing [De Princ.] a connected body of doctrine' (De Princ. I. Pref. 9). Its overarching and 'complete' nature means one doctrine can be seen in conjunction with another.
} 
determines that his audience recognizes this is not a charge to sin that grace may abound.

This is not so for the homilies. The chance to guard each side from misunderstanding is more difficult in a short sermon. Furthermore, here it is much easier to construct an audience. These would have been the congregations of Caesarea who met daily to hear the scriptures expounded by Origen. ${ }^{31}$ One can only anticipate that such congregations would have been comprised of a variety of people at different stages of Christian faith. ${ }^{32}$ Regardless, one must surely acknowledge that a form of 'systematic' theology is very different from homiletics. ${ }^{33}$ The aims are distinct: the former is a philosophical and biblical approach to questions of Christian doctrine; the latter is an exercise in exhortation and challenge for all the people of the Christian church. ${ }^{34}$ It is not surprising, therefore, that the sermons of Origen are largely far less positive than De Princ. on the question of universalism. ${ }^{35}$ Needing to charge the people with a quest for greater holiness, it would be unwise of Origen overly to emphasize the goodness and grace of God so as to mislead people that their salvation was unconnected to their present life of faith. Moreover, Origen's apokatastasis is one which is brought about by spiritual progress either in this age or future aeons: Origen wishes people to progress in faith towards the Logos, and the

\footnotetext{
${ }^{31}$ Butterworth records it was only after the age of 60 that Origen allowed his homilies to be taken down and published. Butterworth, On First Principles, p. xxv.

${ }^{32}$ See Adele M. Castagno, 'Origen the Scholar and Pastor', trans. Frances Cooper, in Mary B. Cunningham and Pauline Allen, eds., Preacher and Audience: Studies in Early Christian and Byzantine Homiletics (Leiden: Brill, 1998), pp. 65-87.

${ }^{33}$ It is also different from commentary. As Trigg argues: '[Origen] treated the homily as a distinct genre from the commentary. His homiletics are more hortatory, much more concise, less technical, and less speculative than his commentaries.' Trigg, Origen, p. 39.

${ }^{34}$ Indeed, Daley notes that it is part of the pastoral concern of Origen that he should emphasize even more than Clement or Irenaeus the continuity between the present life and its eschatological goal: for Origen, eschatological statements have implications for the present. See Daley, The Hope of the Early Church, p. 48.

${ }^{35}$ Castagno suggests that hints at the doctrine of universalism are hidden behind the harsh and fearful biblical dictates, such as the eternal fire. Castagno, 'Origen the Scholar and Pastor', pp. 84f.
} 
force of his homilies reflects this. Thus, Origen preaches regarding, for example, Noah that the story indicates that very few are saved.$^{36}$ On Leviticus, he pronounces: 'For salvation is not for anyone, unless he first makes propitiation for himself to the Lord' (HomLev. V.7.2). ${ }^{37}$ Certainly, the tone in the sermons is different to that of De Princ. on the issue of a possible apokatastasis. Origen, a 'wise steward of the word', is hiding his own position on universalism in case he causes the people to fall into sin. Where positive elements that point towards universalism do exist ${ }^{38}$ they exist in dialectic to this - a dialectic which the challenging and encouraging preacher always seeks to find.$^{39}$ Or else, they are the result of the exegesis of a particular text with which a preacher who preaches from the Bible (as Origen did) must always struggle. Indeed, it is this matter which helps to explain the variety of views contained in a third category of Origen's writings - his commentaries. As Hermann-Josef Vogt has asserted, various traditions are allowed to stand in these. ${ }^{40}$ This is because the bible itself is multi-vocal. ${ }^{41}$ Again, it is difficult to construct an audience for such a work, but one might presume an educated scholar or preacher/priest of the church. For that

\footnotetext{
36 'These, indeed, who live by rational knowledge and are capable not only of ruling themselves but also of teaching others, since very few are found, represent the few who are saved with Noah himself and are united with him in the closest relationship, just as also our Lord, the true Noah, Christ Jesus, has few inmates, few sons and relatives, who are participants in his word and capable of his wisdom' (HomGen. II.3). Trans. Heine, Origen Homilies on Genesis and Exodus.

${ }^{37}$ Translation is taken from Gary W. Barkley, Origen Homilies on Leviticus, The Fathers of the Church (A New Translation), vol. 83 (Washington, DC: The Catholic University of America Press, 1990). ${ }^{38}$ See, for example, HomLev. VII.2.9ff.; HomLk. f.214.

${ }^{39}$ While the force of the preaching described above may seem to be weakened by hints at ultimate universal salvation, it is worth considering that even temporary punishments are worth avoiding. No self-contradiction is present, therefore, in this aspect of Origen's homiletics so long as Origen can persuade his hearers that they still have much to suffer from a lack of faith: to do this, he focuses his hearers on the suffering of the present world and its immediate aftermath in which there is clear differentiation of the Christian from the non-Christian, while still ensuring that hints at ultimate universalism which are present do not detract from this.

${ }^{40}$ Hermann-Josef Vogt, 'Wie Origenes in seinem Matthäus-Kommentar Fragen offen lässt', in Henri Crouzel and Antonio Quacquarelli, eds., Origeniana Secunda (Rome: Edizioni dell'Ateneo, 1980), pp. $191-8$.

${ }^{41}$ Frances Young describes well Origen's struggle to relate the multiplicity of the verses in the Bible to its unity of meaning. See Frances Young, Biblical Exegesis and the Formation of Christian Culture (Cambridge: Cambridge University Press, 1997), pp. $21 \mathrm{ff}$.
} 
reason, where Origen perceives there to be suggestions of universalism in the text, these are presented..$^{42}$ Since they are presented outside the larger schema of Origen's soteriology and eschatology, they are not as overt as his presentation in De Princ. in which he is able to guard against a misunderstanding of this doctrine. However, they are present in the guarded way Origen believes the 'wise steward[s] of the word' in scripture intended. Where scripture speaks in another voice, sometimes from the same 'wise steward of the word' who had pointed towards universalism, this too is recorded and exegeted. ${ }^{43}$

As for Origen's other major work, Contra Celsum, the issue of universalism is very interesting. Rather than indicating the universality of salvation, it appears to suggest the universality of the offer of salvation. Universalism appears to be a universal invitation (CCel. III.63). Moreover, Origen is clear that 'the blessed future life will be for those alone who have accepted the religion of Jesus' (CCel. III.81). Language about Christ being saviour of all, quoted above, need not lead directly to a belief in universalism: it means that Christ's work is offered universally. Indeed, this appears to be the concern in CCel.: Christ came for the whole geographic world - to save people from all nations (CCel. IV.28); and this is contrasted to salvation simply being limited to those in just one corner of the earth (CCel. IV.4). Again, the genre of this work is important to Origen's articulation of exclusivism or universalism. An apologetic work to argue that people should convert to Christianity would hardly be bolstered by an appeal to universalism, however much the author believed it to be ultimately the case. Such a move would be unwise stewardship of scripture.

\footnotetext{
${ }^{42}$ See, for example, CommJoh. VI.284; CommMt. X.2; CommRom. V.2.2, 8.

${ }^{43}$ See, for example, CommRom. III.1.3, V.1.29, 37, VII.8.4, VIII.7.2; CommMt. X.25, XII.12, XIII.17, 25, XIV.17.
} 


\section{Conclusion}

This short article has attempted to consider the apparent contradiction in Origen's work on universalism in light of the issue of genre and the suggested hermeneutical key of CommRom. V.1.7. Many issues concerning apokatastasis have not been discussed: its relation to particularity, to the life of Christ, to sanctification, to time and eternity, to free will and the like. However, it is hoped that this article has pointed towards an important issue regarding universalism for Origen, as he seeks within a pluralist setting to speculate on the salvation of those outside the Christian faith. ${ }^{44}$ Origen wishes to balance a concern and hope for those outside the church with ahope and concern for those within the church. For that reason, in works in which the doctrine of universalism might cause the slowing of progress for believers, punishment and judgement sound fortissimo while universalism sounds only pianissimo. Where this is not the case, the reverse is true. Not only in the commentaries, in which both universalism and exclusivism are heard from the writers of scripture, but throughout his theology, Origen is determinedly biblical even to the point of covering over (as he believes scripture does) the truth of doctrine in order to help the believer in their spiritual progression. Like Paul, he is a

\footnotetext{
${ }^{44}$ On approaches to pluralism, see John F. Dechow, 'Origen and Early Christian Pluralism: The Context of his Eschatology', in Kannengiesser and Petersen, eds., Origen of Alexandria, pp. 337-56. Dechow argues that Origen's use of cultural resources to explain his doctrines is comparable to Tillich's use of 'the principle of correlation' (p. 340), and argues that Origen wished to present his thought against the wider background of thought contemporary to him (pp. 351f.). Certainly, Dechow is correct in claiming Origen's 'expression of Christian doctrine was not for the sake of philosophical exposition, but vice versa' (p. 352). However, it is difficult to imagine Origen consciously utilizing thought contemporary to him in order to engage in a specifically pluralist agenda: the roots and origins of Christianity are such a tangled mess of influence, that Origen is simply following the path laid for him by biblical and apostolic writers who speak of the nascent Christian religion in terms of the parent religion (Judaism) as influenced by Philo and other contemporary Hellenistic thought. Origen's adoption of language and thought from other quarters marks desire to engage in apologetic and even proselytizing, rather than dialogue or correlation of thought.
} 
Greek to the Greek and under the law to one under the law. That Origen is some form of universalist cannot be doubted, but neither can his pastoral concern.

Distasteful as it may be to our post-Reformation and Vatican II ears, the once didaskalos Origen's concern is the same as St Paul's - to be a wise steward, and to do this by fulfilling Paul's principle of feeding infants with milk and those mature in the faith with solid food (1 Cor. 3:1-3). Origen recognizes the danger of the doctrine of universalism if wrongly understood. He is right to do so: many of his later critics fail to understand the particular type and implications of his universalism; no doubt some of his own congregations would also have failed. For that reason, he finds it necessary, dependent on the genre of the work, to cover over at times a belief which he did clearly hold.

For those seeking to articulate a universalist soteriology in the present age such issues must continue to be considered. For the Christian living in a complexly secular and religious world, the desire to express a hope for those neighbours of other faiths and none is significant. Significant, too, is the need to express that greater hope in a way which does not deny or undermine Christian particularity and the faith of the church. While we may not wish to speak in different voices or to cover up what we believe to be the truth for the sake of 'weaker brethren', there is a need to be sensitive to the contexts in which we speak and the emphases we place on certain elements of our tradition, especially with regard to this doctrine.

Universalism should not be expressed in a way which reduces the importance of faith and obedience to a believer; faith and obedience should not be expressed in a way which reduces the love of God for all humanity and the wider hope this brings.

What is more, this one doctrine confronts our discipline with a broader question of 
method. Theology not only includes differing (albeit overlapping) fields of expertise (for example, biblical studies, patristics, church history, systematics); it also has different contexts in which it is expressed and utilized. Present-day theologians are confronted with this complexity, and must not seek to cut themselves off, attending singularly to their own specialisms or presenting their findings only in a narrow context: theology has implications for a whole host of situations and peoples. These situations (whether ecclesial, political, homiletic, inter-faith, pastoral, academic, biblical, systematic, philosophic, historical, scientific or other) must be dealt with sensitively: a sermon does not take place in a seminar room, nor is inter-faith dialogue liturgy, for example. This is not to engage in some kind of deception as a two-faced monster, speaking one truth to one group and another truth to another group. Rather, it is a sensitivity to the way in which the truth must be communicated, and a realization that the differing fields of our discipline overlap and must inform each other. At base, it is a recognition of the need to attend fully to the unity and multi-vocality of scripture in expressing doctrine, and to attempt to understand that unity and multi-vocality theologically. Fundamentally, it is a need to be, in the varied contexts in which we find ourselves, a 'wise steward of the word'. 